\title{
EVALUATION OF USER SATISFACTION FOR PASSER BORDER INFORMATION SYSTEM: THE STATE OF INDONESIA AND TIMOR-LESTE
}

\author{
Fransiskus M. H. Tjiptabudi, Skolastika S. Igon, and Raul Bernardino \\ Study Program of Information System, STIKOM Uyelindo, Kupang, NTT, 85111, Indonesia \\ E-mail: tjiptabudifrans@gmail.com,igonskolastika@yahoo.co.id,bernardino_raul@yahoo.com
}

\begin{abstract}
The administrative process that had previously applied to the cross-border post or 'Pos Lintas Batas Negara (PLBN)' is integrated with the way of manuscript the passport data information or 'Pas Lintas Batas (PLB)'-special card for habitants whereas living a long site of the both countries border (Indonesia and Timor-Leste), information on a card and then do a recapitulation. This manuscript administration gave unfavorable result such as not have proper archiving in the filing cabinet and difficulty of the search data for the report purpose. To solve these problems, then it has been developed and implemented an application which called 'Sistem Informasi Pelintas Batas Wilayah Negara (SINTASWIN)'. This SINTASWIN application is applied to the immigration authorities in order to record and control the border crosser (traveler). This system will support the national policies and strategies of the Government in managing border region. However, the implementation of any application system has it constraints; therefore, it needs to be evaluated such as to evaluate end user satisfaction. This study aims to evaluate the satisfaction of users by applying End User Computing Satisfaction (EUCS) methods in order to produce recommendations for the improvement and system development in the future.
\end{abstract}

Keywords: PLBN, border region, immigration, information system, EUCS

\begin{abstract}
Abstrak
Proses administrasi yang sebelumnya diterapkan pada Pos Lintas Batas Negara (PLBN) terpadu adalah dengan cara menulis data paspor atau Pas Lintas Batas (PLB) pada sebuah kartu kemudian direkapitulasi. Administrasi yang kurang baik tersebut berakibat pada tidak rapinya penyimpanan data dan kesulitan pencarian data serta penyajian laporan. Untuk memecahkan permasalahan tersebut, maka telah dibangun dan diimplementasi sebuah Sistem Informasi Pelintas Batas Wilayah Negara (SINTASWIN) yang diterapkan pada otoritas imigrasi untuk mendata dan mengontrol pelintas batas wilayah guna mendukung kebijakan dan strategi nasional pemerintah dalam pengelolaan wilayah perbatasan perbatasan antarnegara. Tetapi dalam implementasinya, sistem informasi tersebut bukan tanpa kendala, oleh karena itu perlu dilakukan evaluasi salah satunya dari segi kepuasan pengguna akhir dari sistem tersebut. Penelitian ini bertujuan untuk melakukan evaluasi kepuasan pengguna dengan menerapkan metode EUCS (End User Computing Satisfaction) guna menghasilkan rekomendasi untuk perbaikan dan pengembangan sistem pada masa yang akan datang.
\end{abstract}

Kata Kunci: PLBN, wilayah perbatasan, imigrasi, sistem informasi, EUCS

\section{Introduction}

Unitary State of the Republic of Indonesia (so called NKRI) is an island nation and land areas that directly adjacent to three (3) countries namely Malaysia on the Borneo island, Papua New Guinea $(\mathrm{PNG})$ on the Papua island, and Timor-Leste (RDTL) on the Timor island, East Nusa Tenggara province.

Several decades ago, Indonesia border regions face some challenges, among others, the uneven spread of the population as well as the limitations of the infrastructure. The level of education, health and the quality of the Human Resources
(HR) are still relatively low and undeveloped processing industry, so that the activities of the economy still depends on raw products. Similarly, the management of natural resources has a less restrained and weak in information systems and communications. Moreover, it reviewed from the perspective of security, conditions of the borders region of Indonesia is currently at the stage of worrying. It is characterized by the onset of a variety of border issues such as the case of 'Ambalat' Block, the case of the 'Bidadari' island, and the problems of border crosser [1]. The problem is the direction of the development policy which tends to be oriented towards to the inward looking rather than 
become an outlook', -so as if the border region only into the backyard of a country's development. As a result, the border region is not considered as priority area of development by the Central Government as well as regional [2].

To overcome these problems, the Government is currently drafting a national policy and strategy for managing border region between states in Indonesia and set the presidential regulation Number 179 Year 2014, on the border region of the country, especially in the province of East Nusa Tenggara. The form of the implementation of the national policy and strategy is to build border regions; it is including build PLBN with integrated infrastructure to support everything relating to the border region. Such development necessarily must be accompanied by improved management, especially in the field of administration by the authorities on duty in the PLBN.

The immigration authorities as one of the unit works on the integrated PLBN has the responsebility, among others, keep an eye on the traffic of people exiting/entering the territory of Indonesia and providing service to the community; the authorities require applying information technology to improve the quality in the task performance [3]. As it is known, in the last decade, the massive uses of information and communication technology in Government and private organizations have become a necessity. In the private sector, information technology applied to achieve strategic business objectives [4] and creating a competitive advantage [5], meanwhile in the organization and government the use of information and technology applied for the various direction simultaneously [6] and subject to competitive aims [7]. Therefore, the application of information technology is very much needed because basically it can make easier for Government officers to be able to complete tasks or his work without having to take a long time, costs as well as a great power [8]. In this case, the presence of information technology, the services to the public will improve and the process of administrating state border crosser will increase both in terms of time and quality [9].

The expected added value can be felt by the immigration officer whereas the officers are easily doing logging, data recapitulation, and reports which are related to the passer borders of the country. The administration will handy to manage because all data have been computerized, and it is ease for searching and processing data and information. Moreover, the service given to the cross border is faster than a conventional.

In the early stage of the implementation, the expected added value will not directly optimal. It might be just happened the gap between user needs and system behaviors. It includes interactive model and the services provided on the system; therefore, it needs system evaluation by seen user satisfaction.

\section{Methods}

In this research, we applied End User Computing Satisfaction (EUCS) method which will be doing the overall evaluation of the used of information system and end user experiences [10]. The EUCS evaluation model is developed by Doll \& Torkzadeh. This evaluation model emphasizes the satisfaction of the end user against all aspects of the technology, by assessing the Content, Format, Timing, Accuracy, and Ease of Use the system [11]. Based on the EUCS model shows in the Figure 1 and EUCS items are customized as research instruments with current cases (Table 1).

In this research, the object is end user of the SINTASWIN (immigration officers). In integrated PLBN, the immigration officers are distributed three distinct locations as follows: 6 officers at Mota'ain, 5 officers at Motamasin, and 5 officers at Wini post. Therefore, the population for rese-arch are 16 people and this is limited population.

The sampling techniques used in this research are saturated sampling technique, in which the saturated sampling is a technique of determining the sample when all members of a population is used as a sample. This is often done when the population is relatively small, less than 30 persons or who wish to make a generalization of research with a very small mistake. Moreover, saturated sampling term example is a census, whereas all members of the population became sample [12].

The data retrieved through this research is subjected as the primary data type which collected from respondents were answering the listed questionnaire and then analyzed in descriptive statistics by researcher. The descriptive statistics is the statistics analysis toward data collection, in a way describe or illustrate data that has been collected as-is without intending to make general conclusions. In this case study, the type of statistical analysis descriptive by calculating the respondent's responses with the following equation(1) [13]:

$$
\mathrm{CI}=\frac{\sum \mathrm{JR}}{\mathrm{SI}} \times 100 \%
$$

where

CI: 'Capaian Indikator' (Performance Indicator) JR: 'Jawaban Responden' (Respondence Answers) SI: 'Skor Ideal' (Ideal Score)-highest score multiplied by the number of respondents

The results are categorized with the following weighting: 


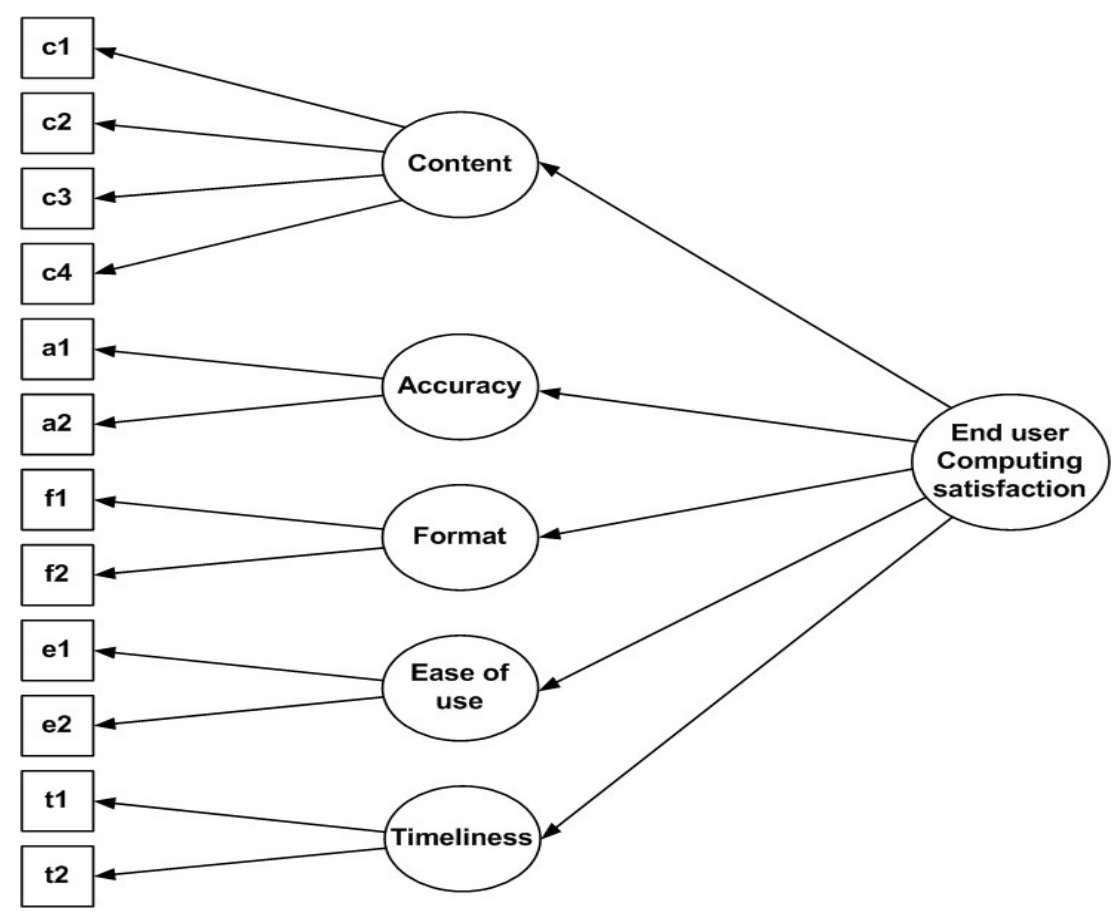

Figure 1. EUCS Model

$0 \%-20 \%=$ Very low

$21 \%-40 \%=$ Low

$41 \%-60 \%=$ High enough

$61 \%-80 \%=$ High

$81 \%-100 \%=$ Very High

The hypothesis that built and will be tested in this study can be seen in Table 2:

\section{Analysis and Result}

For the questionnaire data measurement scale, Likert model is used. The Likert scale models are descriptive such as Strongly Agree (SA) with weights 5, Agree (A) with weights 4, Hesitation (H) or Neutral (N) with weights 3, Disagree (DA) with weights 2, Strongly Disagree (SDA) with weights 1. The analysis of descriptive statistics results toward 16 respondent's responses to the questionnaire can be seen in Table 3 .

Based on the calculation results of the indicator product of any dimensions (Table 3), it can be noted that the average indicators of each dimension are above $80 \%$ figure. There are two dimensions from five dimensions items that have a high result indicator with the average category of $80.63 \%$ namely Ease of Use dimension and Timeliness dimension, whereas the hypothesis (H4) stating that the results of indicators product of the Ease of Use dimension is very high and the hypothesis (H5) stating that the results of indicator product of Timeliness dimension very high, there- fore it is not acceptable. Furthermore, three (3) other hypotheses $\mathrm{H} 1, \mathrm{H} 2$, and $\mathrm{H} 3$ each stated that the results of indicator product of the dimensions such as Content, Accuracy and Format are very high, and it is acceptable. It is demonstrated in Table 3 whereas the average of these third dimensions of the performance indicator is above $81 \%$, therefore it is included in the very high category.

The content dimension has four (4) indicators that shown in Table 1. Based on the result calculation the performance indicator can be concluded that the expected information is met respondents needs. The statement in C4 indicator stated 'The Sintaswin provide sufficient information' which is obtained the lowest average performance indicator of $77.5 \%$, with details of respondents answers i.e. $31.25 \%$ of the respondents answered is neither agree, $50 \%$ of respondents answered is agree and $18.75 \%$ of the respondents answered is strongly agree. It is reasonable because the built system is based on the limited manual sample reports that have been used there before, therefore for further improvement and development will accommodate additional information. Although performance indicator for $\mathrm{C} 1, \mathrm{C} 2$, and $\mathrm{C} 3$, indicate very high category, it does not mean not require repairs or future enhancement. The SINTASWIN should be continually improving to complete both in terms of format or content of the information itself, because an effective content management should meet all the needs of stakeholders [14]. 
TABLE 1

INSTRUMENT COMPARISON

\begin{tabular}{|c|c|c|c|}
\hline $\begin{array}{l}\text { Item } \\
\text { Code }\end{array}$ & Measures & Original Instrument Items & This Study Items \\
\hline $\mathrm{C} 1$ & \multirow[t]{4}{*}{ Content } & $\begin{array}{l}\text { Does the system provide the precise information } \\
\text { you need? }\end{array}$ & $\begin{array}{l}\text { The Sintaswin provides the precise information I } \\
\text { need }\end{array}$ \\
\hline $\mathrm{C} 2$ & & Does the information meet your needs? & The information content meet my needs \\
\hline $\mathrm{C} 3$ & & $\begin{array}{l}\text { Does the system provide reports that seem to be } \\
\text { just about exactly what you need? }\end{array}$ & $\begin{array}{l}\text { The Sintaswin provide reports more than what I } \\
\text { need }\end{array}$ \\
\hline $\mathrm{C} 4$ & & Does the system provide sufficient information? & The Sintaswin provide sufficient information \\
\hline A1 & \multirow[t]{2}{*}{ Accuracy } & Is the system accurate? & The Sintaswin is accurate \\
\hline A 2 & & Are you satisfied with the accuracy of the system? & I am satisfied with the accuracy of the system \\
\hline F1 & \multirow[t]{2}{*}{ Format } & $\begin{array}{l}\text { Do you think the putput is presented in a useful } \\
\text { format? }\end{array}$ & The output is presented in a useful format \\
\hline $\mathrm{F} 2$ & & Is the output information clear? & The information is clear \\
\hline E1 & \multirow[t]{2}{*}{ Ease of use } & Is the system user-friendly? & The Sintaswin is user-friendly \\
\hline E2 & & Is the system easy to use & The Sintaswin is easy to use \\
\hline $\mathrm{T} 1$ & \multirow[t]{3}{*}{ Timeliness } & Do you get information you need in time & I get the information I need in time \\
\hline $\mathrm{T} 2$ & & Does the system provide up-to-date information? & The Sintaswin provides up-to-date information \\
\hline Scale & & $\begin{array}{l}\text { Five-point Likert scale: } \\
\text { 1: Almost never, } 2 \text { : Some of the time, } 3: \text { About } \\
\text { half the time, } 4: \text { Most of the time, } 5: \text { Almost } \\
\text { always }\end{array}$ & $\begin{array}{l}\text { Five-point Likert scale: } \\
\text { 1: Strongly disagree, 2: Disagree, } 3: \text { Neither } \\
\text { agree nor disagree, } 4: \text { Agree, 5: Strongly agree }\end{array}$ \\
\hline
\end{tabular}

The SINTASWIN user's satisfaction against aspects of accuracy is measured based on 2 (two) indicators. The average indicator of the accuracy dimension indicates $83.13 \%$ which makes it fall very high category. It can be spelled out that as much as $87.5 \%$ of respondents declared satisfied with the accuracy of SINTASWIN, while the rest of $12.5 \%$ were indicates very satisfied. Although it is in very high category, however the performance indicator of $83.13 \%$ indicated that the accuracy of this system could still be improved in the future. The accuracy enhancement is important whereas the proper decision-making must be based on accurate information. It is in line with the test results and model validation of the EUCS of 1,166 respondents from 300 different applications which gives the conclusion that the accuracy is more important in user satisfaction for the ope-rating personnel [15].

The format dimension turned out to have close results or same performance indicator with the accuracy dimension whereas falls in the very high category of $83.13 \%$. For the F1 performance indicators as much as $81.25 \%$ of respondents gave agree answers the rest of $18.75 \%$ gave strongly agree answers, while performance indicators for F2 indicates that $87.5 \%$ of respondents answered agree and the remaining $12.5 \%$ replied strongly agrees. The results show that aspects of the format and clarity of the report still needs improvement.

The Ease of Use dimension, the performance indicator as much as $80.63 \%$, it grouped in the high categories. On every indicator of this dimension, there are $12.5 \%$ respondents who answered the neutral or undecided. Especially F2 indicator only acquires an indicator of $80 \%$. Both facts show that there are still shortcomings in terms of system interfaces, which makes the user experience const- raints in the operation of the system. The main cause factors are not yet fully matching interface design with existing standards. The standards that can be used to support the future development of the user interface that is to: 1) determine the details of the display and use be-havior interface is using ISO 14915 and IEC 61997 which are containing multimedia interface recommendations. More specific guidelines for the use of the icon can be found on the ISO/IEC 11581, PDAs in ISO/IEC 18021, and cursor control in ISO/IEC 10741; 2) provide detailed guidance about designing the user interface (ISO 9241 Part 12-17); and 3) provide the criteria for the evaluation of the user interface (ISO/IEC 9126 Parts 2 and 3).

However, by default, required attributes of a product to be used depend on the nature of the user, task, and environment [16]. Furthermore, the standard is required the availability of the SINTASWIN manual book. Although the system socialization has been done, however user may have trouble therefore manual book is needed.

The last dimension is the Timeless dimension. This dimension measured system timekeeping in the process of presenting information. The two result indicators whereas $18.75 \%$ of the respondents were stating neutral or undecided against item statements on the questionnaires. The remainning average indicators are $80.63 \%$ at high categories. Based on information above, it can be concluded that the SINTASWIN process is not yet entirely fast or it still takes quite a long time.

The implications of the research results can be viewed from two aspects, namely the aspects of systems and it is infrastructure. The assessment given by the user in the aspect of the system is very useful for the improvement and future SINTASWIN development, this is to achieve a more stable 
TABLE 2

RESEARCH HYPOTHESIS

\begin{tabular}{ll}
\hline Hypothesis \\
\hline H1 & $\begin{array}{l}\text { The performance indicator of content dimension } \\
\text { is very high } / \mathrm{CI}>=81 \%\end{array}$ \\
$\mathrm{H} 2$ & $\begin{array}{l}\text { The performance indicator of accuracy } \\
\text { dimension is very high } / \mathrm{CI}>=81 \%\end{array}$ \\
$\mathrm{H} 3$ & $\begin{array}{l}\text { The performance indicator of format dimension } \\
\text { is very high } / \mathrm{CI}>=81 \%\end{array}$ \\
$\mathrm{H} 4$ & $\begin{array}{l}\text { The performance indicator of ease of use } \\
\text { dimension is very high / } \mathrm{CI}>=81 \%\end{array}$ \\
H5 & $\begin{array}{l}\text { The performance indicator of timeless } \\
\text { dimension is very high } / \mathrm{CI}>=81 \%\end{array}$ \\
\hline
\end{tabular}

system and precise in delivering outputs and the information in accordance with users need and to the stakeholders decision-making processes.

Some of the infrastructure are already available in an integrated PLBN is very effect to the system performance. Looking at user satisfaction performance in terms of speed (timeliness dimension) of a system, then the local network infrastructure should be taken into consideration, i.e. servers, clients, and switches that must perform well.

\section{Conclusion}

In general, the user satisfaction in using of the SINTASWIN quite positive according to the performance indicators results, because the existence of this system can be a solution for the administration problems that had occurred in the immigration services in the three integrated PLBN in East Nusa Tenggara. Moreover, further development of the SINTASWIN need to pay attention to the implications of this research results both aspects of the system and the infrastructure.

\section{References}

[1] M. Indra, "Urgensi Pengelolaan Wilayah Perbatasan Dalam Kaitannya Dengan Kedaulatan Negara Kesatuan Republik Indonesia', Jurnal Selat, vol. 1, no. 1, pp. 13-18, 2013.

[2] F. Rani, "Strategi Pemerintah Indonesia Dalam Meningkatkan Keamanan Wilayah Perbatasan Menurut Perspektif Sosial Pembangunan", Jurnal Transnasional, vol. 4, no. 1, pp. 102-115, 2012.

[3] Efendi, "Studi Tentang Pelayanan Publik Pas Lintas Batas (PLB) Krayan-Ba'kelalan Malaysia Di Kantor Imigrasi Kecamatan Krayan Kabupaten Nunukan", eJournal Ilmu Administrasi Negara, vol. 3, no. 2, pp. 613-627, 2014.

[4] A. Chircu and D. Lee, "Understanding IT Investments in The Public Sector: The Case Of e-Government", in Proceedings of the Ninth Americas Conference on Information Systems, pp. 792-800, 2003.
TABLE 3

\begin{tabular}{|c|c|c|c|}
\hline Dimension & $\begin{array}{l}\text { Item } \\
\text { Code }\end{array}$ & $\begin{array}{l}\text { Performance } \\
\text { Indicator }\end{array}$ & Category \\
\hline \multirow[t]{5}{*}{ Content } & $\mathrm{C} 1$ & 88,75 & Very High \\
\hline & $\mathrm{C} 2$ & 87,50 & Very High \\
\hline & $\mathrm{C} 3$ & 82,50 & Very High \\
\hline & $\mathrm{C} 4$ & 77,50 & High \\
\hline & Average & 84,06 & Very High \\
\hline \multirow[t]{3}{*}{ Accuracy } & A1 & 83,75 & Very High \\
\hline & $\mathrm{A} 2$ & 82,50 & Very High \\
\hline & Average & 83,13 & Very High \\
\hline \multirow[t]{3}{*}{ Format } & $\mathrm{F} 1$ & 83,75 & Very High \\
\hline & $\mathrm{F} 2$ & 82,50 & Very High \\
\hline & Average & 83,13 & Very High \\
\hline Ease in & E1 & 81,25 & Very High \\
\hline \multirow[t]{2}{*}{ use } & E2 & 80,00 & High \\
\hline & Average & 80,63 & High \\
\hline \multirow[t]{3}{*}{ Timeliness } & $\mathrm{T} 1$ & 80,00 & High \\
\hline & $\mathrm{T} 2$ & 81,25 & Very High \\
\hline & Average & 80,63 & High \\
\hline
\end{tabular}

[5] B. Rocheleau and L. Wu, "Public Versus Private Information System: Do They Differ in Important Ways? A Review and Empirical Test", American Review of Public Administration, vol. 32, no. 4, pp. 379-397, 2002.

[6] D. Farnham and S. Horton, "Managing the New Public Services", Palgrave Macmillan, 1996.

[7] M.M. Kamal, "IT Innovation Adoption In The Government Sector: Identifying The Critical Success Factors", Journal of Enterprise Information Management, vol. 19, no. 2, pp. 192-222, 2006.

[8] Z.A. Hasibuan and S.P. Utomo, "Perancangan Sistem Informasi Manajemen Keimigrasian (SIMKIM)", Jurnal sistem Informasi Dan Manajemen Teknologi Informasi, vol. 1, no. 1. 2012.

[9] F. Alandri, "Peran Sistem Informasi Manajemen Berbasis Komputer Dalam Meningkatkan Pelayanan Publik Di Lingkungan Kantor Bupati Kabupaten Berau", eJournal Ilmu Pemerintahan, vol. 1, no. 1, p. 182-194. 2013.

[10] W.W. Chin and M.K. Lee, "On the Formation of End-User Computing Satisfaction: a Proposed Model and Measurement Instrument", in Proceeding of the $21^{\text {st }}$ International Conference on Information System, vol. 553, pp. 563, 2000.

[11] W.J. Doll and G. Torkzadeh, "The Measurement of End-User Computing Satisfaction", MIS Quarterly, vol. 12, no. 2, pp. 259-274, 1988.

[12] Sugiyono, "Metode Penelitian Kuantitatif Kualitatif dan R\&D”, Alfabeta, Bandung, p. 147, 2012.

[13] Riduwan, "Skala Pengukuran Variabel-Variabel Penelitian", Alfabeta, Bandung, p. 59, 2006. 
[14] P. Tyrvăinen, T. Păivărinta, A. Salminen, and J. Iivari, "Characterizing the Evolving Research on Enterprise Content Management", European Journal of Information Systems, vol. 15, no. 6, pp. 627-634, 2006.

[15] W.J. Doll, D. Xiadong, T.S. Raghunathan, G. Torkzadeh and W. Xia, "The Meaning and Measurement of User Satisfaction: a Multi- group Invariance Analysis of the End-User Computing Satisfaction Instrument", Journal of Management Information Systems, vol. 21, no. 1, pp. 227-262, 2004.

[16] N. Bevan, "International Standards for HCI and Usability", International Journal Human -Computer Studies, vol. 55, pp. 533-552, 2001. 